\title{
Effects of foliar application of BAP on source and sink strength in four six-rowed barley (Hordeum vulgare $\mathrm{L}_{\text {.) }}$ cultivars
}

Shahab Maddah Hosseini · Kazem Poustini •

Ali Ahmadi · Reza Tavakkol Afshari

(C) Springer Science+Business Media B.V. 2008

Erratum to: Plant Growth Regul

DOI 10.1007/s10725-007-9245-4

Co-author's name was missing in the original article.

Dr Reza Tavakkol Afshari should be read as co-author of this article.

The online version of the original article can be found under doi:10.1007/s10725-007-9245-4.

S. Maddah Hosseini $(\square) \cdot$ K. Poustini

A. Ahmadi · R. Tavakkol Afshari

Department of Agronomy and Plant Breeding,

University College of Agriculture and Natural Resources,

University of Tehran, Karaj, Iran

e-mail:shmaddah@ut.ac.ir 